\title{
Investigation of Students' Opinions on Distance Education in the COVID-19 Pandemic Process
}

\author{
Ebru Güzel Kuyucu (Corresponding author) \\ Faculty of Sports Science, Trabzon University, Trabzon, Turkey \\ Tel: 90-507-657-8686 E-mail: ebruguzel@trabzon.edu.tr
}

Serkan Kabak

Faculty of Sports Science, Trabzon University, Trabzon, Turkey

Tel: 90-507-155-12-37_E-mail: serkankabak@trabzon.edu.tr

Received: November 5, 2021 Accepted: December 5, 2021

Published: December 31, 2021

doi:10.5296/jei.v7i3.19264 URL: https://doi.org/10.5296/jei.v7i3.19264

\begin{abstract}
Due to the worldwide COVID-19 epidemic, distance education has become a necessity rather than a choice in order to ensure the continuity of education at all educational levels. This research was carried out to examine the opinions of students on the distance education process applied in universities during the COVID-19 Pandemic period. Sample of study consists of 153 students ( 73 female, 80 male), who were selected by simple random sampling method, studying at Trabzon University Faculty of Sport Sciences. In the study, Opinions for Distance Education Scale (OFDES) and personal information form were used. The scale was developed by Y1ldırım et al. (2014) and consists of 18 items and 4 factors. Data were collected through an online survey. The collected data were analyzed with the SPSS program. Descriptive statistics, T-Test and ANOVA analyses were used in the research. It shows that students' satisfaction with distance education conducted during the COVID-19 epidemic is at a low level $(\overline{\mathrm{x}}=2.03 ; \mathrm{Sd}=.55)$. In other words, students prefer face-to-face education to distance education. In the gender variable, it was determined that male students $(\overline{\mathrm{x}}=2.75$; $\mathrm{Sd}$ $=.54)$ had a higher mean score than female students $(\overline{\mathrm{x}}=2.48 ; \mathrm{Sd}=.53)$. In the study, some suggestions have been developed in order to make the distance education process more efficient from the students' perspective.
\end{abstract}

Keywords: COVID-19 pandemic, Distance education, Student Opinions 


\section{Introduction}

The COVID-19 pandemic (epidemic), which started in China on 31 December 2019 and spread rapidly all over the world, has caused a worldwide crisis in the field of education as well as in the fields of health, economy and social life (Can, 2020). In this process, which confined the whole world to its home, the activities of almost all educational institutions in the world were interrupted. In order to control the Pandemic in the world, many countries had to temporarily suspend education in schools and universities (WHO, 2020a). The coronavirus, defined as a global epidemic (pandemic) by the World Health Organization, has alarmed the whole world (WHO, 2020b). Nearly 1.5 billion students and approximately 63 million teachers in 165 countries around the world have been severely affected by the epidemic due to the interruption of face-to-face education (UNESCO, 2020). For this reason, the need for the management of the crisis created by an indefinite and unpredictable epidemic in every field, especially in education, has emerged in the world (UNESCO, 2020).

With the closure of schools, all countries have started to seek urgent solutions in order to ensure that students can continue their education and training activities. Considering the spread and contagiousness of COVID-19, distance education has been the effective way for people to continue their education without endangering their health (Emin, 2020). During the pandemic process, many countries in the world have started to implement emergency precaution packages in which digital technologies are effective and, they have tried to ensure the continuity of education (Angoletto \& Queiroz, 2020). With the first case seen in Turkey, education was suspended for three weeks as of March 16, 2020 at the Higher Education level (Higher Education Board, 2020a). However, due to the rapid spread of the epidemic, the increase in cases and as the end of the epidemic process cannot be foreseen, it was decided to continue the term with distance education (Higher Education Board, 2020b).

Distance education is an education model in which time and space flexibility is provided, communication and interaction are established in online environments, the instructor and the trainer are physically in separate places, and face-to-face and other education, methods and techniques are used together (Aydemir, 2018). Distance education, which has emerged as an alternative to face-to-face education, is an important change in the field of education thanks to the internet and information technologies. However, during the extraordinary Pandemic process in the world, distance education has become the only system in the world where education is carried out rather than an alternative to face-to-face education (Koç, 2021).

In Turkey, studies on distance education at the higher education level have started since the 1950s. In the 1950s-1970s, distance education experiments were made with tools such as radio, TV and letters. In the 1980s, Turkish universities were given the right of distance and continuous education, and Open Education Faculty was established within Anadolu University. In the 1990s, distance education experiments were carried out at Firat University, first by e-mail and then by TV broadcast. Some lessons were learned through videoconferencing from the USA. Istanbul Technical University established a distance education center and Middle East Technical University started distance education applications. In the $2000 \mathrm{~s}$, the interest in distance education increased, and conferences, 
workshops and collaborations between universities were carried out with distance education applications. Today, during the pandemic epidemic, infrastructure studies have been provided to carry out the courses completely from distance in universities, and centers for distance education (UZEM) have been developed (Yagan, 2021; Doğan News Agency, 2020).

In order to reduce the negative effects of the coronavirus epidemic on education worldwide, distance education has come to the fore, and also it was understood that it is necessary to invest more in distance education, and it is necessary to give importance to alternative learning approaches together with traditional education approaches in order to ensure the continuity of education (Can, 2020). It is important that the distance education system, which is seen as the most ideal alternative to the continuation of education in times of crisis, is effectively structured in order to achieve success in all learning environments. For this, all components such as students, teachers, environment and content that make up the distance education system should be examined, an effective analysis should be made, and the system should be properly planned, designed, managed and evaluated as a result of the analysis (Y1ldiz, 2015). In the literature, it is stated that there is a need for students, who are the main users of distance education, to reveal their perspectives on distance education, the problems they encounter in the system, and their wishes (Y1ldırım, 2010).

The opinions, attitudes and approaches of the students about distance education, which is the most important component of the education system, provide important data in terms of providing information about the quality, acceptability and dimensions, which need improvement, of such programs (Tavşanc1l, 2019; Tryon and Bishop, 2009). Furthermore, students' opinions about their learning environment, their thoughts and positive or negative feelings about the distance education program are also important (Petty \& Cacioppo, 1996). In other words, knowing the attitudes of the students towards the distance education program can make important contributions to creating the educational environments of educational institutions that provide applied education, especially sports sciences, for similar crisis situations in the future. In this context, the study aims to determine the educational opinions of the sports science faculty students who continue their education with the distance education system due to the COVID-19 epidemic.

\section{Method}

\subsection{Research Model}

The study is a descriptive study in survey model. In this study, a descriptive survey model was used as it was tried to determine the educational opinions of the sports science faculty students who continue their education with the distance education system due to the COVID-19 epidemic. This is because survey models are suitable for studies aiming to describe a past or present situation as it is (Büyüköztürk et al., 2008).

\subsection{Sample of Study}

The study consists the students of the Faculty of Sport Sciences of Trabzon University, who have been continuing their education with the distance learning system since March 23, 2020, due to the end of face-to-face education because of the COVID pandemic. 153 undergraduate 


\section{Macrothink}

students aged between 18 and 33 participated in the study.

\subsection{Data Collection Tools}

Study data was obtained through Personal Information Form and Opinions for Distance Education Scale.

\subsubsection{Personal Information Form}

This form is based on literature knowledge and previous studies on distance education (Birişçi et al., 2011; İşman, 2011; Odabaş, 2003; Özgöl et al., 2017; Y1ldırım et al., 2014; Mollaoğlu, 2021). In this form, questions such as age, gender, class, department were asked to the students.

\subsubsection{Opinions for Distance Education Scale (OFDES)}

The validity-reliability of the scale, which consists of 18 items and includes 4 sub-dimensions of Personal Suitability, Effectiveness, Instructiveness and Predisposition, were made for Turkey. The questions were prepared in the form of a 5-point Likert (1-never agree, 5-always agree). The Opinions for Distance Education Scale consists of a total of 18 questions. The Personal Suitability sub-dimension of the scale consists of six items, the Effectiveness sub-dimension consists of five items, the Instructiveness sub-dimension consists of four items, and the Predisposition sub-dimension consists of three items. The scale is between 18-90 points in total, and an increase in the score means a positive opinion towards distance education. The Cronbach Alpha coefficient of the scale was found to be 0.86 (Yildirim et al., 2014).

\subsection{Application}

The list of students was obtained from the faculty secretariat, the students were reached through the class representatives, and a statement explaining the purpose of the research was written and online data collection forms were sent to the students, and the feedbacks were evaluated.

\subsection{Data Analysis}

Data analysis was done in SPSS 22.0 package program. Descriptive statistical tests such as frequency, percentage, minimum, maximum, arithmetic mean, standard deviation (SD) were used in the analysis of the data. Evaluations were made with $95 \%$ confidence level criteria.

\subsection{Ethical Aspect of Research}

Before starting the research, permission to use the scale was obtained from the authors, who made the Turkish validity and reliability of the scales used in the research, via e-mail. In order to implement this study, necessary permissions were obtained from the Social and Human Sciences Scientific Research and Publication Ethics Committee of Trabzon University. 


\section{Results}

Table 1. Distribution of scale scores

\begin{tabular}{|l|l|l|l|l|l|l|l|l|}
\hline & Number of Item & Mean & Sd & Skewness & Kurtosis & Min. & Max. & Cronbach Alpha \\
\hline OFDES & 18 & 2.03 & 0.55 & 0.12 & 0.05 & 1.17 & 4.22 & .80 \\
\hline Personal Suitability & 6 & 2.56 & 1.12 & 0.43 & -0.62 & 1.00 & 5.00 & .89 \\
\hline Effectiveness & 5 & 1.97 & 0.98 & 1.19 & 1.07 & 1.00 & 5.00 & .91 \\
\hline Instructiveness & 4 & 4.08 & 1.13 & -1.22 & 0.66 & 1.00 & 5.00 & .89 \\
\hline Predisposition & 3 & 1.90 & 0.85 & 1.09 & 1.24 & 1.00 & 5.00 & .75 \\
\hline
\end{tabular}

The arithmetic mean, standard deviation, skewness and kurtosis values and cronbach alpha values (OFDES .80, Personal Suitability .89, Effectiveness .91, Instructiveness .89, Predisposition .75) of the total scores of the students within the scope of the research from the opinions for distance education scale and its sub-dimensions are given in Table 1. While the lowest score of the students of the faculty of sports sciences within the scope of the research from the opinions for distance education scale is 1.17 , the highest score is 4.22 . When the skewness and kurtosis values of the scores obtained from the opinions for distance education scale and its sub-dimensions (Table 1) are examined, it can be said that the data show a normal distribution since they are in the range of -1.5-1.5. Students' satisfaction with distance education is low. When the scale scores are analyzed on the basis of factors, it is seen that the mean of effectiveness and predisposition sub-dimensions are low.

Table 2. T-Test results according to gender variable

\begin{tabular}{|c|c|c|c|c|c|c|}
\hline & \multicolumn{2}{|c|}{ Female $(\mathrm{n}=73)$} & \multicolumn{2}{|c|}{ Male $(\mathrm{n}=80)$} & \multirow{2}{*}{$\mathrm{t}$} & \multirow{2}{*}{$\mathrm{p}$} \\
\hline & Mean & $\mathrm{Sd}$ & Mean & $\mathrm{Sd}$ & & \\
\hline OFDES & 2.48 & 0.53 & 2.75 & 0.54 & 3.00 & 0.00 \\
\hline Personal Suitability & 2.25 & 1.02 & 2.84 & 1.14 & 3.35 & 0.00 \\
\hline Effectiveness & 1.76 & 0.82 & 2.17 & 1.07 & 2.70 & 0.01 \\
\hline Instructiveness & 4.30 & 1.08 & 3.89 & 1.14 & -2.28 & 0.02 \\
\hline Predisposition & 1.77 & 0.76 & 2.02 & 0.90 & 1.80 & 0.07 \\
\hline
\end{tabular}

In Table 2, the T-Test results of the students' scores on the Opinions for Distance Education scale and its sub-dimensions are given according to the gender variable. The analyses show 
that the OFDES total score differs significantly according to the gender variable $(t=3.00, p<$ $0.01)$. According to this finding, the mean scores of male students $(\bar{x}=2.75)$ are higher than the mean scores of female students $(\bar{x}=2.48)$. In other words, it can be said that male students' opinions for distance education are more positive than female students. When the scale scores are examined on the basis of factors, it is seen that the dimensions of suitability, effectiveness, and instructiveness differ significantly according to the gender variable, while there is no significant difference in the sub-dimension of predisposition. According to this finding, the mean scores of male students $(\overline{\mathrm{x}}=2.84),(\overline{\mathrm{x}}=2.17)$ are higher than the mean scores of female students $(\bar{x}=2.25),(\bar{x}=1.76)$ in the sub-dimensions of suitability and effectiveness. In the instructiveness sub-dimension, the mean scores of female students $(\overline{\mathrm{x}}=$ 4.30) are higher than the mean scores of male students $(\overline{\mathrm{x}}=3.89)$.

Table 3. ANOVA results according to class variable

\begin{tabular}{|c|c|c|c|c|c|c|c|c|c|c|c|}
\hline & \multicolumn{2}{|c|}{$\begin{array}{l}1^{\text {st }} \text { Grade } \\
(\mathrm{n}=33)\end{array}$} & \multicolumn{2}{|c|}{$\begin{array}{l}2^{\text {nd }} \text { Grade } \\
(\mathrm{n}=52)\end{array}$} & \multicolumn{2}{|c|}{$\begin{array}{c}3^{\text {rd }} \text { Grade } \\
(n=35)\end{array}$} & \multicolumn{2}{|c|}{$\begin{array}{l}4^{\text {th }} \text { Grade } \\
(n=33)\end{array}$} & \multirow[t]{2}{*}{$\mathrm{F}$} & \multirow[t]{2}{*}{$\mathrm{p}$} & \multirow[t]{2}{*}{ Significant Difference } \\
\hline & Mean & $\mathrm{Sd}$ & Mean & $\mathrm{Sd}$ & Mean & $\mathrm{Sd}$ & Mean & $\mathrm{Sd}$ & & & \\
\hline OFDES & 2.77 & 0.39 & 2.42 & 0.57 & 2.65 & 0.61 & 2.77 & 0.52 & 4.17 & 0.00 & $1-2 ; 4-2$ \\
\hline Personal Suitability & 2.77 & 1.01 & 2.34 & 0.98 & 2.53 & 1.22 & 2.89 & 1.22 & 2.95 & 0.03 & $4-2$ \\
\hline Effectiveness & 2.21 & 0.98 & 1.71 & 0.76 & 1.97 & 1.07 & 2.16 & 1.13 & 2.32 & 0.07 & - \\
\hline Instructiveness & 4.15 & 1.05 & 4.06 & 1.19 & 4.14 & 1.19 & 3.99 & 1.07 & 0.15 & 0.93 & - \\
\hline Predisposition & 1.88 & 0.59 & 1.81 & 0.86 & 2.04 & 0.98 & 1.92 & 0.90 & 0.53 & 0.67 & - \\
\hline
\end{tabular}

Table 3 shows the ANOVA test results of the students' scores on the Opinions for Distance Education scale and its sub-dimensions according to the class variable. According to the class variable, the analyses show that the scores obtained from the Opinions for Distance Education scale $\left(\mathrm{F}_{3.149}=4.17, \mathrm{p}<0.01\right)$ and Personal Suitability $\left(\mathrm{F}_{3.768}=2.95, \mathrm{p}<0.05\right)$ sub-dimension differ significantly, whereas the scores of Effectiveness $\left(\mathrm{F}_{3.149}=2.32, \mathrm{p}>\right.$ $0.05)$, Instructiveness $\left(\mathrm{F}_{3.149}=0.15, \mathrm{p}>0.05\right)$, Predisposition $\left(\mathrm{F}_{3.149}=0.53, \mathrm{p}>0.05\right)$ sub-dimensions did not differ significantly. Tukey test, one of the post hoc tests, was used to understand between which variables there was a significant difference. When the total scores obtained from the scale as a result of the test are examined, it is seen that the mean scores of the $1^{\text {st }}$ grade students $(\bar{x}=2.77)$ are statistically higher than the mean scores of the $2^{\text {nd }}$ grade students $(\bar{x}=2.42)$, while the mean scores of the $4^{\text {th }}$ grade students $(\bar{x}=2.77)$ are statistically higher than the mean scores of the $2^{\text {nd }}$ grade students $(\bar{x}=2.42)$. When the scale scores are analyzed on the basis of factors, it is seen that in the personal suitability sub-dimension, the mean scores of the $4^{\text {th }}$ grade students $(\bar{x}=2.89)$ are statistically higher than the mean scores of the $2^{\text {nd }}$ grade students $(\bar{x}=2.34)$. In other words, it can be said that the opinions of $1^{\text {st }}$ and $4^{\text {th }}$ grade students about distance education are positive in terms of total scale and personal suitability (Table 3 ). 
Table 4. ANOVA results according to department variable

\begin{tabular}{|c|c|c|c|c|c|c|c|c|c|}
\hline & \multicolumn{2}{|c|}{$\operatorname{PEAST}(\mathrm{n}=54)$} & \multicolumn{2}{|c|}{$\mathrm{CT}(\mathrm{n}=31)$} & \multicolumn{2}{|c|}{$\operatorname{SM}(n=68)$} & \multirow{2}{*}{$\mathrm{F}$} & \multirow{2}{*}{$\mathrm{p}$} & \multirow{2}{*}{ Significant Difference } \\
\hline & Mean & $\mathrm{Sd}$ & Mean & $\mathrm{Sd}$ & Mean & $\mathrm{Sd}$ & & & \\
\hline OFDES & 2.69 & 0.55 & 2.80 & 0.53 & 2.49 & 0.54 & 3.97 & 0.02 & $2-3$ \\
\hline Personal Suitability & 2.64 & 1.14 & 2.69 & 1.25 & 2.44 & 1.05 & 0.78 & 0.46 & - \\
\hline Effectiveness & 2.17 & 1.05 & 2.23 & 1.02 & 1.70 & 0.85 & 5.04 & 0.00 & $1-3 ; 2-3$ \\
\hline Instructiveness & 4.06 & 1.22 & 4.10 & 1.16 & 4.10 & 1.05 & 0.02 & 0.98 & - \\
\hline Predisposition & 1.85 & 0.85 & 2.21 & 1.04 & 1.80 & 0.72 & 2.81 & 0.06 & - \\
\hline
\end{tabular}

Note. 1: PEAST Physical Education and Sports Teaching; 2: CT Coaching Training; 3: SM Sports Management.

Table 4 shows the ANOVA test results of the students' scores on the Opinions for Distance Education scale and its sub-dimensions according to the department variable. The analyses show that the scores obtained from the Opinions for Distance Education scale $\left(\mathrm{F}_{2.150}=3.97, \mathrm{p}\right.$ $<0.05)$ and the Effectiveness $\left(\mathrm{F}_{2.150}=5.04, \mathrm{p}<0.05\right)$ sub-dimension differ significantly according to the department variable, whereas the scores of Personal Suitability $\left(\mathrm{F}_{2.150}=0.78\right.$, $\mathrm{p}>0.05)$, Instructiveness $\left(\mathrm{F}_{2.150}=0.02, \mathrm{p}>0.05\right)$, Predisposition $\left(\mathrm{F}_{2.150}=2.81, \mathrm{p}>0.05\right)$ sub-dimensions do not differ significantly. Tukey test, one of the post hoc tests, was used to understand between which variables there was a significant difference. When the total scores obtained from the scale are examined as a result of the test, it is seen that the mean scores of the students of the coaching department $(\bar{x}=2.80)$ are statistically higher than the mean scores of the students of the sports management department $(\overline{\mathrm{x}}=2.49)$. When the scale scores are analyzed on the basis of factors, in the effectiveness sub-dimension, it is seen that the mean scores of the students of Physical education and sports teaching department $(\bar{x}=2.17)$ and the mean scores of the students of the coaching training department $(\bar{x}=2.23)$ are statistically higher than the mean scores of the students of the sports management department $(\bar{x}=1.70)$. In other words, when the total scale scores are examined, it can be said that results were obtained in favor of the students of coaching education, and in the effectiveness sub-dimension, results were obtained in favor of the students of both coaching education and physical education and sports teaching departments. In other words, it can be said that the opinions of the students of the department of coaching education and physical education and sports teaching towards distance education are more positive than the students of the sports management department (Table 4).

\section{Discussion}

In this study, the majority of sports science students did not find the distance education system suitable for them. The results of the research show that students' satisfaction with distance education carried out during the COVID-19 epidemic is at a low level. Students 
prefer face-to-face education to distance education. Studies in the literature support the finding that there is a low level of attitude towards distance education during the epidemic period. Study by Keskin and Özer-Kaya (2020) on university students, study by Altuntaş-Y1lmaz (2020) on Physiotherapy and Rehabilitation Department students, study by Serçemeli and Kurnaz (2020) on university students taking accounting courses, study by Kurt (2020) on nursing students, study by Young and Özer-Kaya (2020) on nursing students, study by Gumrukcuoglu (2020) on the students of the Faculty of Theology, study by Kahraman (2020) on university students taking the basic design course, study by Karatepe, Küçükgençay and Peker (2020) on teacher candidates, study by Unger and Meiran (2020), and Rizun and Strzelecki (2020) on university students revealed that the attitudes and opinions of the students towards distance education were not positive. Aktaş, Büyüktaş, Gülle, and Yildiz (2020), on the other hand, evaluated student opinions both for the epidemic period and after the epidemic, unlike the researchers above, in their study on sports science students. Researchers revealed that half of the students were in favor of continuing distance education during the epidemic, but after the epidemic, the vast majority preferred face-to-face education. This study also supports the finding that students prefer face-to-face education to other models when they return to normal conditions.

Mean scores of the students, particularly, from the effectiveness and predisposition sub-dimension of OFDES were found to be low. This low level shows that students do not find the distance education system effective for sports sciences and they are not inclined to distance education. In addition, according to the students' mean score of instructiveness sub-dimension, it was concluded that face-to-face interaction is necessary for the best education, ideas are shared instantly and clearly in face-to-face education compared to distance education, face-to-face communication is needed for learning, and face-to-face education is a more effective learning method. In addition, it was concluded in the study that the satisfaction levels of students towards distance education differ according to demographic variables such as gender, class level and department.

As a result, students do not have enough positive attitudes towards distance education. Since the research has the prediction that distance education will be applied more frequently in the future (Yamamoto \& Altun, 2020), it is important to take measures that will bring the attitudes of students towards distance education to a positive level.

The COVID-19 pandemic has caused significant effects and changes in many fields, especially in education, in Turkey as in the world, and the distance education system has temporarily replaced face-to-face education as an alternative education method (Emin, 2020). This study includes the opinions of students who continue their sports science education asynchronously with the distance education system in only one state university during the COVID-19 pandemic process. This is considered a limitation of the study. In terms of generalizability of the results, it is recommended that the study be conducted on a wider student population in different universities. In addition, in order to make distance education more applicable in fields such as sports sciences in similar situations in the future, studies should be carried out to strengthen the infrastructure of this teaching model and to improve its content and design in similar programs, especially in the university where the research was 
conducted. It is thought that the results of the study will contribute to being prepared to create similar situations for the future and to provide data for the plans to be made in the next process.

\section{References}

Aktaş, Ö., Büyüktaş, B., Gülle, M., \& Yıldız, M. (2020). Attitudes of sports science students towards distance education during the days of isolation caused by the COVID-19 virus. Sivas Cumhuriyet University Journal of Sport Sciences, 1(1), 1-9.

Altuntaş-Yılmaz, N. (2020). Investigation of students' attitudes about the distance education situation applied during the COVID-19 pandemic process in higher education institutions: The example of the Physiotherapy and Rehabilitation Department. Journal of Necmettin Erbakan University Faculty of Health Sciences, 3(1), 15-20.

Angoletto, R., \& Queiroz, V. C. (2020). COVID-19 and the challenges in education. The Centro de Estudos Sociedade e Tecnologia, 5(2), 1-2

Aydemir, M. (2018). Distance Education Program, Course and Material Design. Education Publisher.

Birişçi, S., Metin, M., \& Demiryürek G. (2011). Examination of primary school teachers' attitudes towards computer and internet use: The case of Artvin. Journal of Educational Technologies Research, 2(4), 1-18.

Büyüköztürk, Ş., Çakmak, E. K., Akgün, Ö. E., Karadeniz, S., \& Demirel, F. (2008). Scientific research methods (2nd ed.). Pegem Academy.

Can, E. (2020). Coronavirus (COVID-19) pandemic and its pedagogical reflections: Open and distance education practices in Turkey. $A U A d, 6(2), 11-53$.

Doğan News Agency. (2020). The President of YÖK has announced, distance education is becoming widespread. Retrieved from https://www.trthaber.com/haber/gundem/yok-baskaniacikladiuzaktan-ogretim-yayginlasiyor 489831.html

Emin, M. N. (2020). Education during the coronavirus pandemic and emergency. Seta/Perspective, 268, 1-4. Retrieved from https://setav.org/assets/uploads/2020/04/P268.pdf

Genç, M. F., \& Gumrukcuoglu, S. (2020). Views of theology faculty students to distance education during the coronavirus (COVID-19) period. Turkish Studies, 15(4), 403-422.

Isman, A. (2011). Distance education (4th Edition). Ankara: Pegem Academy Publishing.

Hero, M. E. (2020). The effect of the COVID-19 epidemic on applied courses and the conduct of these courses with distance education: An example of a basic design course. Civilization Art Journal, 6(1), 44-56.

Karatepe, F., Küçükgençay, N., \& Peker, B. (2020). How do prospective teachers view synchronous distance education? A survey study. Journal of Social and Humanities Sciences Research, 7(53), 1262-1274. https://doi.org/10.26450/jshsr.1868 


\section{Macrothink

Keskin, M., \& Ozer-Kaya, D. (2020). Evaluation of students' feedback on web-based distance education during the COVID-19 process. Journal of Izmir Katip Celebi University Faculty of Health Sciences, 5(2), 59-67.

Koç, E. S. (2021). What Kind of Distance Education? Evaluation of the Studies Done at the End of 1 Year. Journal of Social Sciences, 7(2), 13-26.

Kurduncu, M., \& Kurt, A. (2020). The problems experienced by nursing students about distance education during the COVID-19 pandemic. Journal of Eurasian Social and Economic Studies, 7(5), 66-77.

Mollaoglu, S. (2021). Views of a university's art education students on distance education during the COVID-19 pandemic. Journal of Atatürk University Kazım Karabekir Education Faculty, 42, 431-443.

Odabaş, H. (2003). Internet-based distance education and information and document management departments. Turkish Librarianship, 17(1), 22-36.

Özgöl, M., Sarıkaya, M., \& Öztürk, M. (2017). Student and instructor evaluations on distance education practices in formal education. Journal of Higher Education and Science, 7(2), 294-304. https://doi.org/10.5961/jhes.2017.208

Petty, R. E., \& Cacioppo, J. T. (1996). Attitudes and persuasion: Classic and contemporary approaches. Colorado: Westviev Press.

Rizun, M., \& Strzelecki, A. (2020). Students' acceptance of the COVID-19 impact on shifting higher education to distance learning in Poland. International Journal of Environmental Research and Public Health, 17. https://doi.org/10.3390/ijerph17186468

Serçemeli, M., \& Kurnaz, E. (2020). A research on students' perspectives on distance education and distance accounting education during the COVID-19 pandemic period. International Journal of Social Sciences Academic Research, 4(1), 40-53.

Tavsancil, E. (2019). Measuring attitudes and data analysis with SPSS (2nd ed.). Nobel Scholar.

Tryon, P. J., \& Bishop, M. (2009). Theoretical foundations for enhancing social connectedness in online learning environments. Distance Education, 30(3), 291-315. https://doi.org/10.1080/01587910903236312

Yagan, S. A. (2021). Attitudes and Opinions of University Students towards Distance Education Conducted During the COVID-19 Epidemic. Academic Platform Journal of Education and Change, 4(1).

Yildiz, M. (2015). Relationship between the knowledge, beliefs and practices of the instructors who teach in distance education programs (Master's thesis, Hacettepe University, Ankara).

Yildirım, F. (2010). Perspectives of the instructors and students, who are the main elements of the transition to the distance education system. In G. T. Yamamoto, U. Demiray, \& M. 


\section{Macrothink}

Section (Eds.), E-Learning in Turkey: Developments and Applications (pp. 27-48). Ankara: Plato.

Yıldırım, S., Yıldırım., G., \& Çelik, E. (2014). Distance education students' views on distance education: A scale development study. Journal of Education and Training Research, 3(3), $365-370$.

UNESCO. (2020). COVID-19 educational disruption and response. Retrieved April 20, 2021, from https://en.unesco.org/COVID19/educationresponse

Unger, S., \& Meiran, W. R. (2020). Student attitudes towards online education during the COVID-19 viral outbreak of 2020: Distance learning in a time of social distance. International Journal of Technology in Education and Science, 4(4), 256-266. https://doi.org/ 10.46328/ijtes.v4i4.107

Council of Higher Education. (2020a). Coronavirus (COVID-19) Information Note: 1. Retrieved from https://www.yok.gov.tr/Sayfalar/Haberler/2020/coronavirus_bilgilendirme_ 1.aspx

Council of Higher Education. (2020b). Press briefing. Retrieved from https://COVID19.yok. gov.tr/Documents/alinan-kararlar/03-uzaktan-egitimeiliskin-alinan-karar.pdf

WHO. (2020a). WHO Director-General's opening remarks at the media briefing on COVID-19. Retrieved March 15, 2021, from https://www.who.int/dg/speeches/detail/whodirector-general-sopening-remarks-at-the-media -briefing-on-COVID-19---11-march-2020

WHO. (2020b). Coronavirus disease (COVID-19) outbreak situation. Retrieved March 15, 2021, from https://www.who.int/emergencies/diseases/novel-coronavirus-2019

\section{Copyright Disclaimer}

Copyright for this article is retained by the author(s), with first publication rights granted to the journal.

This is an open-access article distributed under the terms and conditions of the Creative Commons Attribution license (http://creativecommons.org/licenses/by/3.0/). 